\title{
IDENTIFICATION OF ROCK BOLT LENGTH IN SITU CONDITIONS
}

\author{
Andrzej STANIEK \\ Central Mining Institute, Plac Gwarkow 1, 40-166 Katowice, Poland, e-mail: astaniek@gig.eu
}

Abstract

A rock bolt which is grouted into the rock strata may not be installed according to the assumed project. It concerns also cases where due to practical reasons it is impossible to drill a hole with a sufficient deepness. The consequence of that is that it is necessary to cut the rock bolt accordingly. Another case is where the rock bolt is damaged, cut or bent. Than it is desirable to check the quality of supporting elements - installed rock bolts and the length of insertion. In proposed paper an outline of a method for measurement of rock bolt length is presented. The method uses ultrasonic transducers and is based on a pulse emission of an impulse wave. As ultrasonic transducer works both as an emitter and receiver, the reflected wave is measured and the length of the object or the position of a crack or damage may be diagnosed.

Keywords: mine, rock bolt, support system, diagnosis, ultrasonic transducer

\section{IDENTYFIKACJA DŁUGOŚCI ŻERDZI KOTWIOWEJ W WARUNKACH IN SITU}

\section{Streszczenie}

Żerdź kotwiowa, która jest wklejona w górotworze może być zamocowana nie zgodnie z założonym projektem. Dotyczy to również tych przypadków, w których ze względu na uwarunkowania techniczne nie możliwe jest odwiercenie otworu na zamierzoną głębokość. Konsekwencją tego jest konieczność skrócenia żerdzi odpowiednio do głębokości otworu. Innym powodem skrócenia żerdzi jest jej uszkodzenie, zerwanie lub zgięcie. W związku $\mathrm{z}$ tym jest zasadnym zdiagnozowanie poprawności działania zabezpieczenia kotwowego. W przedstawiony artykule opisana została metoda pomiaru długości żerdzi kotwiowych. W metodzie stosowane są głowice ultradźwiękowe, działające jako nadajnik i odbiornik sygnałów impulsowych. Impuls - fala ultradźwiękowa generowana przez głowicę odbija się od przeszkody, końca żerdzi lub uszkodzenia i powraca do punktu wymuszenia. Przez pomiar czasu pomiędzy wymuszeniem i odbiorem impulsu oraz na podstawie znajomości prędkości rozchodzenia się fali ultradźwiękowej długość żerdzi lub odcinka żerdzi jest wyznaczana.

Słowa kluczowe: górnictwo, żerdź, obudowa kotwiowa, diagnostyka, głowica ultradźwiękowa

\section{INTRODUCTION}

Rock bolts are widely used as support elements in underground mines (coal, copper, zinc, lead, etc.) and civil tunnels $[10,17,20]$. The function of the rock bolt support system is to anchor and reinforce the rock zone in the near field of an underground opening to deeper rock strata[5, 10]. The rock bolt consists of a steel bar grouted in an oversize hole. Predominantly for that purpose steel rock bolts are used [10]. The distance on which supported rock zone is anchored is very crucial and variations in bolt loading could be attributed to changes in bolt length $[6,16]$. For shorter lengths of rock bolts only adjacent zone is anchored and when rock strata moves that zone may become unstable [6, 8]. Important for proper design of a support system is knowledge about physical parameters of rock strata which have to be estimated experimentally and properly introduced to a projected design [6, 19]. As high transfer loads can be achieved even for short embedment lengths [20] and though new rock bolt load measuring devices are proposed [14], pull testing methods appear as not sufficient diagnostic tool. Another problem is that in order to minimize the effort of building a support system installers may be prone to shorten rock bolts in the process of installation. These factors makes prevention much worse and relevant attendance should be paid both to proper installation as well as sufficient length of rock bolts. The problem is well recognized in mining industry and many researches took effort to solve the problem of better monitoring of quality of rock bolt support systems. Smart sensors techniques are introduced for observation of behavior of grouted rock bolts [5] as well as load measurements at the head of it [7]. Many laboratories and research centers have developed methods for proper diagnose of both loading and length of used support designs. The non-destructive procedure for the determination of force within the installed rock bolt was invented as Ground Anchorage Integrity Testing GRANIT [1, 18]. In Boltometer [1, 3] piezoelectric crystals as generating and receiving sensors were applied for grouting quality control. The method for determination of position of anomalies in grout using ultrasound guided waves was proposed in Rock Bolt Tester [1, 2]. Also for 
estimation of rock bolt length certain methods are investigated, based on stress wave reflection for example [12, 13].

For crack or failure diagnosis of mechanical structures the developed methods named as nondestructive testing (NDT) may be grouped as: ultrasonic testing, echo methods, shadow methods, methods of resonance, radiographic testing, penetration testing, electromagnetic and thermal testing [20]. The ultrasonic testing plays a great role in the global industry and ultrasonic techniques are seen as the most developed NDT techniques. The continuous development of hardware capabilities is focused on fast diagnosis and shortening the time of research [1]. Also different apparatus and equipment are involved in such measurements including large steered ultrasonic test systems using squirters to inspect large contours parts [21]. The ultrasonic transducers (probes) are commonly used in diagnosis of mechanical structures. The most crucial parameters of ultrasonic probes are pulse shape, frequency spectrum, sensitivity and amplitude of the impulse. These parameters should be periodically checked in the overall quality assurance [15]. There are different types of ultrasonic probes, which may be used both as a transmitter and a receiver, as well as doubletransducer probes for detecting point-type discontinuities [11]. Also new methods are involved as acoustic emission beamforming, which is particularly applicable to complex plate-like structures [6] and a matrix array techniques used for ultrasonic evaluation of adhesive joints of metal sheets [8]. For determination of rock bolt length or its failure position the following ultrasonic method is proposed.

\section{DESCRIPTION OF THE METHOD}

The proposed method is complementary to quality assessment of resin layer of fully grouted rock bolts also proposed by the author. The measurement environment and experimental setup for that application are shown in Figure 1.

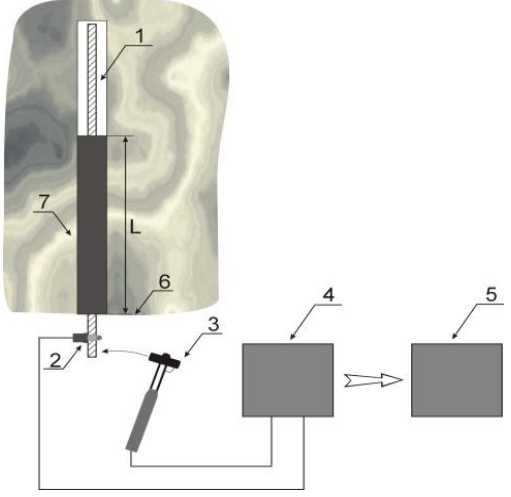

Fig. 1. Experimental setup for estimation of grout discontinuity: 1 - rock bolt; 2 accelerometer; 3- impact hammer; 4portable measuring system; 5- workstation for modal analysis; 6- surface of upper roof section; 7- grout layer, $\mathrm{L}$ is a grouted length.
However in this article the problem of identification of rock bolts length is analyzed. The diagnosis is realized using the same portable measuring system but different transducers and programs, shown in Figure 2.

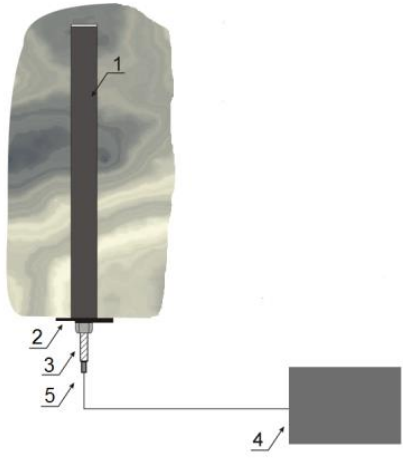

Fig. 2. Experimental setup for ultrasonic measurements: 1-grout layer; 2- plate and nut; 3- rock bolt, typical length $1.5 \mathrm{~m}-2.5 \mathrm{~m}$;

4- portable measuring system; 5ultrasonic probe.

The method uses ultrasonic transducers (probes) and is based on a pulse emission of an impulse wave. The measurement system consists of a Compact RIO controller, a bidirectional digital I/O module NI 9401 which can acquire and generate digital signals at multiple logic levels, a pulser and receiver circuit which enable the adjustment of the transmitter voltage directly from a controller. The digital module starts the trigger, consequently the rising edge of the trigger signal initiates the transducer charging process which takes about 3 us. After this time a transistor switch which discharges the transducer is turned on (discharge time is about $20 \mathrm{~ns})$. Because of the very low output impedance of the device $(<1 \mathrm{Ohm})$ and short discharge time the pulse generated with this device could be concerned as a real pulse answer. The ultrasonic probe works both as an emitter and receiver. The reflected wave generates an electric signal, which is then amplified to change the logic level of a Schmitt inverse circuit and goes back to the digital module. The start digital impulse (raising edge of the trigger digital impulse that causes the trigger) is synchronized with on board clock (40 MHz). The time delay between the start impulse and received digital impulse is evaluated. The length of the object or the position of a crack or damage may then be diagnosed.

Consequent reflections, if present are measured in the same way. The sensitivity of the method is $0.005 \mathrm{~V}$ what enables the measurement of very small reflections, though separation from noise is then necessary. At that stage envelope analysis has not been used to detect the pulse return. As a programming tool the LabVIEW environment was used [4]. The front panel and programing code (graphical language) are shown in Figures 3 and 4. The signal which is received in the transceiver mode depends on the transducer used and here a 
type with medium frequency of about $2 \mathrm{MHz}$ (and pulse length of about $20 \mathrm{~ns}$ ) was used.

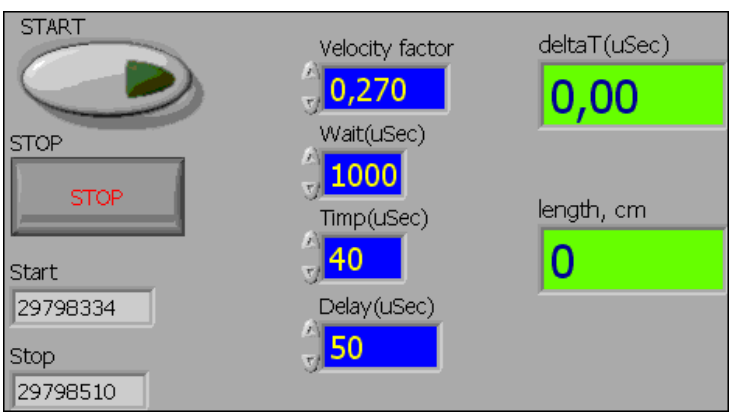

Fig. 3. The user front panel for measurement of rock bolt length

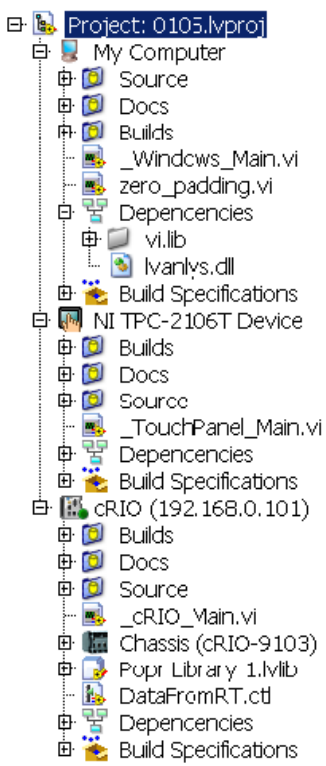

Fig. 4. The program structure in graphical language.

The program diagram for proposed method written in LabVIEW graphical language is shown in Figure 5. The electrical circuit for the ultrasonic transducer measurement chain is presented in Figure 6.

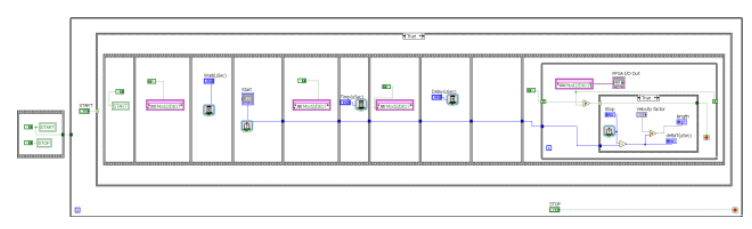

Fig. 5. Part of program diagram for realized measurement method written in LabVIEW graphical language.

Knowing the velocity of propagating waves the measurement of rock bolt length is calculated according to formula 1 . The example signals generated and recorded in portable measuring system are shown in Figure 7.

$$
\Delta L=\frac{1}{2} \cdot v \cdot\left(t_{R}-t_{E}\right)
$$

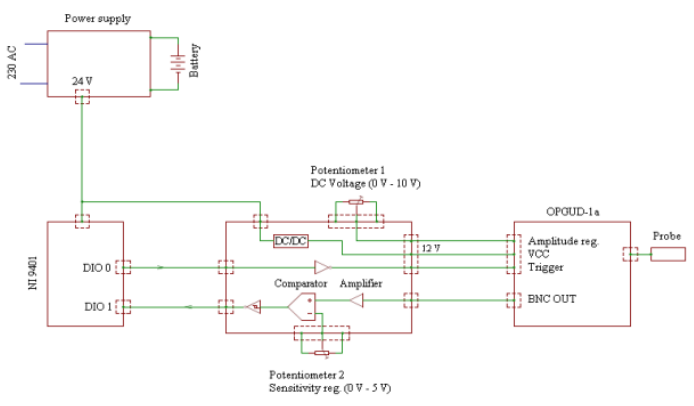

Fig. 6. The electrical circuit for the ultrasonic transducer measurement chain.

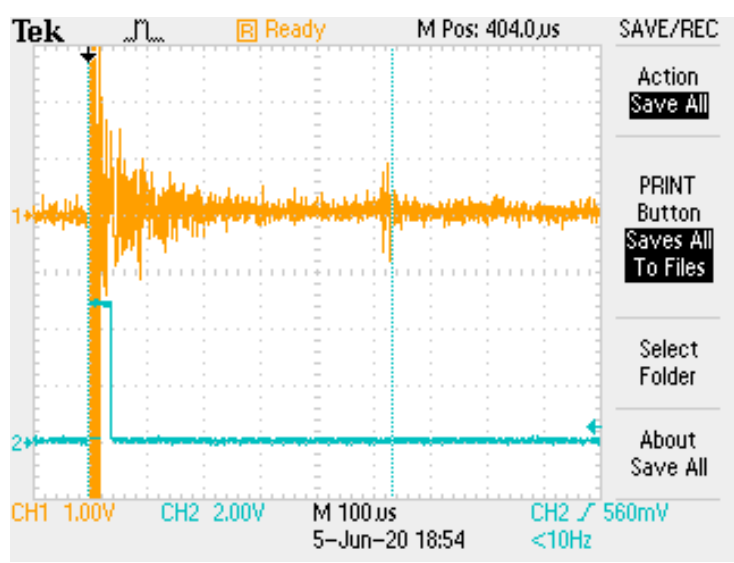

Fig. 7. A generated signal and a received signal reflected from the end of the bolt (upper curve) together with a trigger signal (lower curve). An oscilloscope used as additional monitor.

where:

$v-$ is velocity of propagating wave,

$t_{E}-$ is time when an ultra-high frequency (UHF) impulse is generated,

$t_{R}$ - is time when an ultra-high frequency (UHF) impulse is received.

The upper curve presents the analog signal measured at the output of the ultrasonic transducer (probe). The first impulse is a signal generated after triggering, the second one represents a wave reflected from the end of a rock bolt. The lower curve is a trigger TTL signal.

\section{RESULTS OF UNDERTAKEN WORK}

As a result of undertaken work the apparatus portable measuring system was constructed and application that enable the measurement of the length of rock bolts was uploaded. The front and back side of the apparatus is shown in Figure 8 and 9. 


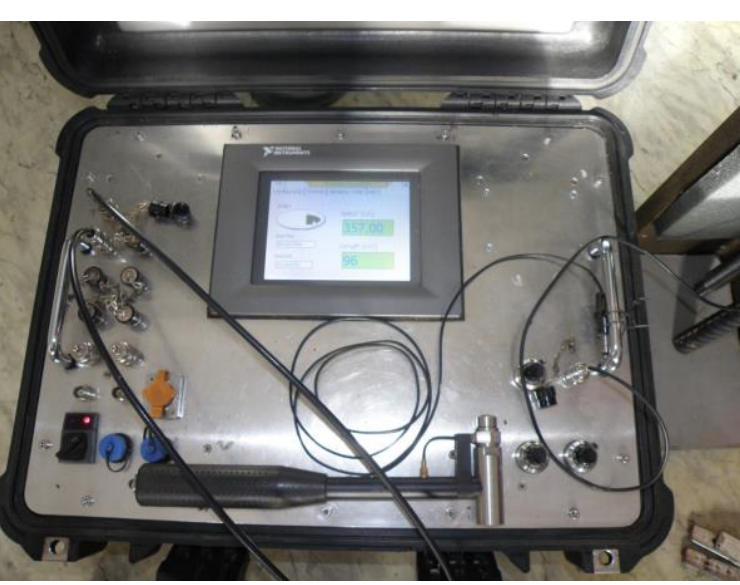

Fig. 8, Apparatus for measurement of quality of rock bolt installation and rock bolt length.(front side).

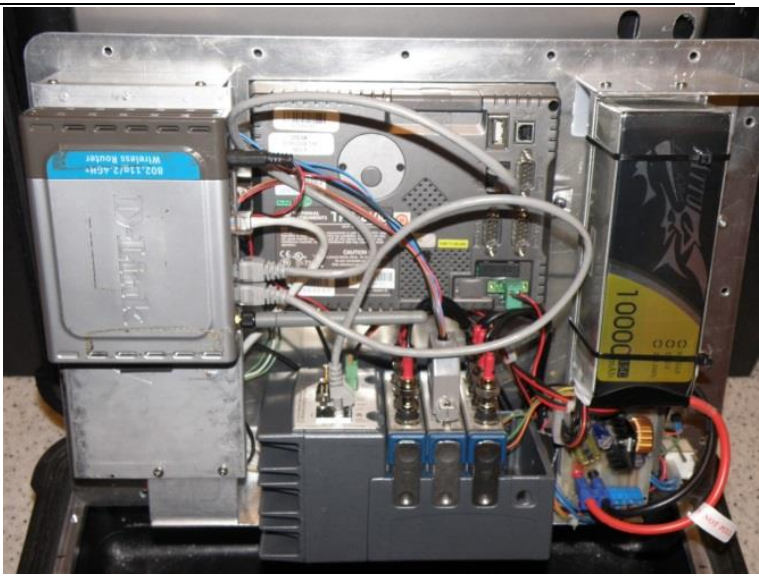

Fig. 9. Apparatus for measurement of quality of rock bolt installation and rock bolt length.(back side).

In order to verify the proposed method the research was performed on different objects with different length or diameter. The examples of rock bolts under test -different length and coating (without grout, grouted and with grout layer only) are shown in Figure 10.

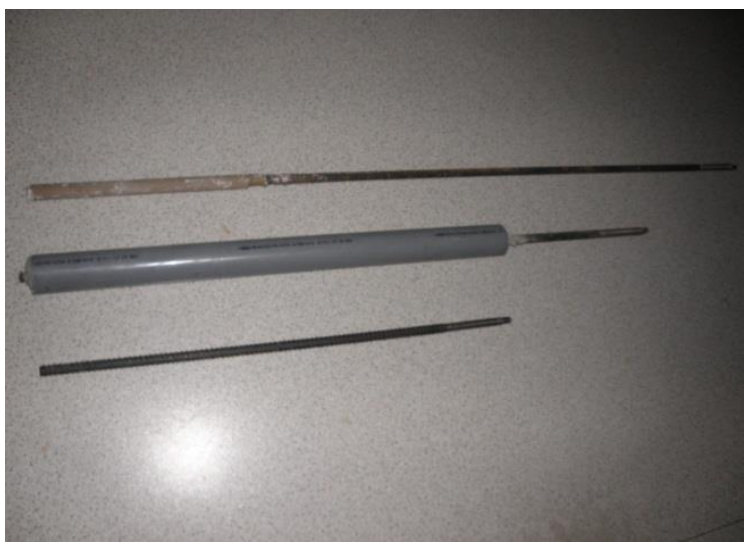

Fig. 10. Different rock bolts under test different length and coating (without grout, grouted and with grout layer only)

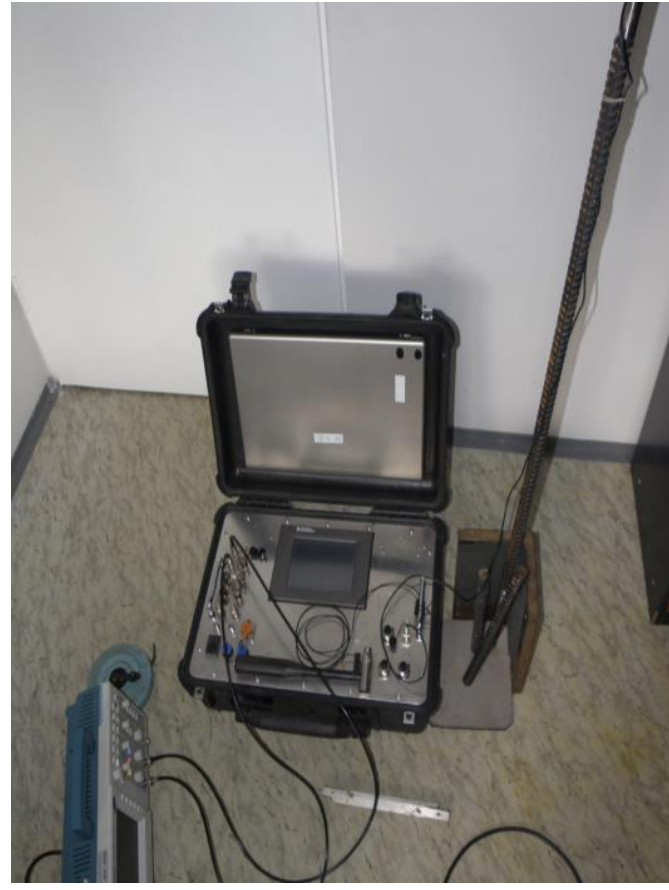

Fig. 11. The example of the measurement process.

In laboratory conditions the measured length was compared with the length identified using a tape measure. The example results of undertaken study are presented in tables 1 to 3 below. For measured lengths the average value and standard deviation (type A standard uncertainty - according to International vocabulary of metrology terms, VIM) were calculated. Also type B evaluation of measurement uncertainty was performed (based on authoritative published quantity values as sound velocity in steel materials, accuracy class of measuring instruments and declarations of producer of measuring modules). Then expanded combined standard measurement uncertainty was obtained which covers two-sigma intervals and incudes both type A and type B uncertainties.

Table 1. The measured length of the investigated rock bolt, using ultrasonic method, the laboratory stage.

\begin{tabular}{|c|c|c|c|}
\hline \multirow{2}{*}{ No } & \multicolumn{2}{|c|}{ Measured parameters } & Difference, \\
\cline { 2 - 3 } & Time, $\mu \mathrm{s}$ & Length, $\mathrm{m}$ & \\
\hline 1 & 332.0 & 0.90 & -10.0 \\
\hline 2 & 351.0 & 0.95 & -5.0 \\
\hline 3 & 352.0 & 0.95 & -5.0 \\
\hline 4 & 356.0 & 0.96 & -4.0 \\
\hline 5 & 356.0 & 0.96 & -4.0 \\
\hline 6 & 352.0 & 0.95 & -5.0 \\
\hline 7 & 353.0 & 0.95 & -5.0 \\
\hline 8 & 357.0 & 0.96 & -4.0 \\
\hline 9 & 381.0 & 1.03 & 3.0 \\
\hline 10 & 351.0 & 0.96 & -4.0 \\
\hline Average & 354.1 & 0.96 & -4.3 \\
\hline Std. Dev. & 11.8 & 0.03 & 3.1 \\
\hline & & $\mathrm{u}_{\mathrm{B}}$ & 6.5 \\
\cline { 3 - 4 } & & $\mathrm{U}_{\mathrm{A}+\mathrm{B}}$ & 14.4 \\
\cline { 2 - 3 } & & &
\end{tabular}

The measured length of the investigated rock bolt, using a measure type equals to $1.0 \mathrm{~m}$. 
Table 2. The measured length of the investigated rock bolt, using ultrasonic method, the laboratory stage.

\begin{tabular}{|c|c|c|c|}
\hline \multirow{2}{*}{ No } & \multicolumn{2}{|c|}{ Measured parameters } & Difference, \\
\cline { 2 - 3 } & Time, $\mu \mathrm{s}$ & Length, $\mathrm{m}$ & \\
\hline 1 & 521.0 & 1.41 & -6.0 \\
\hline 2 & 526.0 & 1.42 & -5.3 \\
\hline 3 & 527.0 & 1.42 & -5.3 \\
\hline 4 & 526.0 & 1.42 & -5.3 \\
\hline 5 & 527.0 & 1.42 & -5.3 \\
\hline 6 & 526.0 & 1.42 & -5.3 \\
\hline 7 & 521.0 & 1.41 & -6.0 \\
\hline 8 & 531.0 & 1.43 & -4.7 \\
\hline 9 & 526.0 & 1.42 & -5.3 \\
\hline 10 & 521.0 & 1.41 & -6.0 \\
\hline Average & 525.2 & 1.42 & -5.5 \\
\hline Std. Dev. & 3.3 & 0.01 & 0.4 \\
\hline \multicolumn{2}{r}{} & $\mathrm{u}_{\mathrm{B}}$ & 6.5 \\
\cline { 3 - 4 } & & $\mathrm{U}_{\mathrm{A}+\mathrm{B}}$ & 13.0 \\
\hline
\end{tabular}

The measured length of the investigated rock bolt, using a measure type equals to $1.5 \mathrm{~m}$.

Table 3. The measured length of the investigated rock bolt, using ultrasonic method, the laboratory stage.

\begin{tabular}{|c|c|c|c|}
\hline \multirow{2}{*}{ No } & \multicolumn{2}{|c|}{ Measured parameters } & Difference, \\
& Time, $\mu$ s & Length, $\mathrm{m}$ & \\
\hline 1 & 704.0 & 1.90 & -5.0 \\
\hline 2 & 689.0 & 1.86 & -7.0 \\
\hline 3 & 688.0 & 1.86 & -7.0 \\
\hline 4 & 703.0 & 1.90 & -5.0 \\
\hline 5 & 687.0 & 1.85 & -7.5 \\
\hline 6 & 688.0 & 1.86 & -7.0 \\
\hline 7 & 734.0 & 1.98 & -1.0 \\
\hline 8 & 689.0 & 1.86 & -7.0 \\
\hline 9 & 677.0 & 1.83 & -8.5 \\
\hline 10 & 708.0 & 1.91 & -4.5 \\
\hline Average & 696.7 & 1.88 & -6.0 \\
\hline Std. Dev. & 16.2 & 0.04 & 2.2 \\
\hline & & $\mathrm{uB}_{\mathrm{B}}$ & 6.5 \\
\cline { 3 - 4 } & & $\mathrm{U}_{\mathrm{A}+\mathrm{B}}$ & 13.6 \\
\cline { 3 - 4 } & & &
\end{tabular}

The measured length of the investigated rock bolt, using a measure type equals to $2.0 \mathrm{~m}$.

In realized measurements slight underestimating of propagating velocity was observed what may be attributed to different velocity of propagating wave than assumed. The value of velocity of sound in steel materials was not changed for all stages of investigation, though possible bias was included in uncertainty budget calculations. That systematic measurement error may be corrected and calibration of the measuring system for known type of rock bolts is possible. What caused certain problems was roughness of the surface at the end of the tested specimen. The problem is somewhat similar to problems encountered when placing the accelerometer on different objects [11]. In practice additional preparation of the contact surface between a rock bolt and an ultrasonic transducer is demanded - the use of a file and glasspaper to polish that surface. Also a special gel utilized for measurements with ultrasonic transducers was used. Other suitable coupling materials for measurements at normal temperatures may include, various oils and greases, glues and silicone fluids.

The final stage of realized research was measurement of rock bolts length in real working conditions in an experimental coal mine. The measurements were performed on several rock bolts grouted in sand stone strata, shown in Figure 12. All the tested rock bolts were of the same lengths, but with different grout layer.

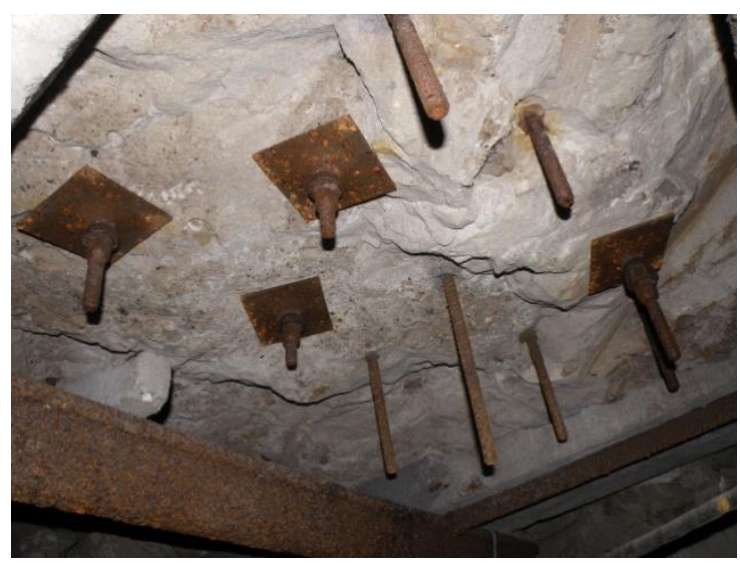

Fig. 12. Investigated rock bolts in the experimental coal mine.

The results are presented in tables 4 and 5 . In Figure 13 and 14 the example trial is shown.

Table 4. The measured length of the investigated rock bolt, ultrasonic method in the experimental coal mine.

\begin{tabular}{|c|c|c|c|}
\hline \multirow{2}{*}{ No } & \multicolumn{2}{|c|}{ Measured parameters } & \multirow{2}{*}{$\begin{array}{c}\text { Difference, } \\
\%\end{array}$} \\
\hline & Time, $\mu \mathrm{s}$ & Length, $\mathrm{m}$ & \\
\hline 1 & 672.0 & 1.81 & -9.5 \\
\hline 2 & 772.0 & 2.08 & 4.0 \\
\hline 3 & 688.0 & 1.86 & -7.0 \\
\hline 4 & 703.0 & 1.90 & -5.0 \\
\hline 5 & 680.0 & 1.84 & -8.0 \\
\hline 6 & 691.0 & 1.87 & -6.5 \\
\hline 7 & 727.0 & 1.96 & -2.0 \\
\hline 8 & 620.0 & 1.67 & -16.5 \\
\hline 9 & 759.0 & 2.05 & 2.5 \\
\hline 10 & 644.0 & 1.74 & -13.0 \\
\hline Average & 695.6 & 1.88 & -6.1 \\
\hline Std. Dev. & 47.3 & 0.13 & 6.4 \\
\hline & & $\mathrm{u}_{\mathrm{B}}$ & 6.5 \\
\hline & & $\mathrm{U}_{\mathrm{A}+\mathrm{B}}$ & 18.2 \\
\hline
\end{tabular}

The length of the investigated rock bolt, according to project, equals to $2.0 \mathrm{~m}$.

Table 5. The measured length of the investigated rock bolt, ultrasonic method in the experimental coal mine.

\begin{tabular}{|c|c|c|c|}
\hline \multirow{2}{*}{ No } & \multicolumn{2}{|c|}{ Measured parameters } & Difference, \\
\cline { 2 - 3 } & Time, $\mu \mathrm{s}$ & Length, $\mathrm{m}$ & 30.7 \\
\hline 1 & 726.0 & 1.96 & 22.7 \\
\hline 2 & 683.0 & 1.84 & 17.3 \\
\hline 3 & 653.0 & 1.76 & 28.0 \\
\hline 4 & 711.0 & 1.92 & 30.0 \\
\hline 5 & 722.0 & 1.95 & 14.7 \\
\hline 6 & 637.0 & 1.72 & 17.3 \\
\hline 7 & 652.0 & 1.76 & \multicolumn{2}{|c}{} \\
\hline
\end{tabular}




\begin{tabular}{|c|c|c|c|}
\hline 8 & 662.0 & 1.79 & 19.3 \\
\hline 9 & 626.0 & 1.69 & 12.7 \\
\hline 10 & 625.0 & 1.69 & 12.7 \\
\hline Average & 669.7 & 1.81 & -9.6 \\
\hline Std. Dev. & 38.6 & 0.10 & 5.2 \\
\hline \multirow{2}{*}{} & $\mathrm{u}_{\mathrm{B}}$ & 6.5 \\
\cline { 2 - 4 } & $\mathrm{U}_{\mathrm{A}+\mathrm{B}}$ & 16.6 \\
\hline
\end{tabular}

The length of the investigated rock bolt, according to project, equals to $2.0 \mathrm{~m}$.

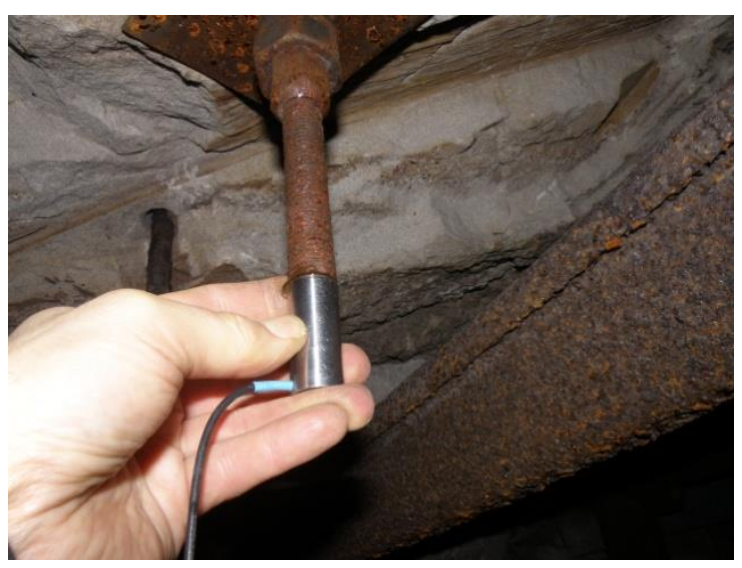

Fig. 13. The measurement of rock bolt length using ultrasonic transducer (probe).

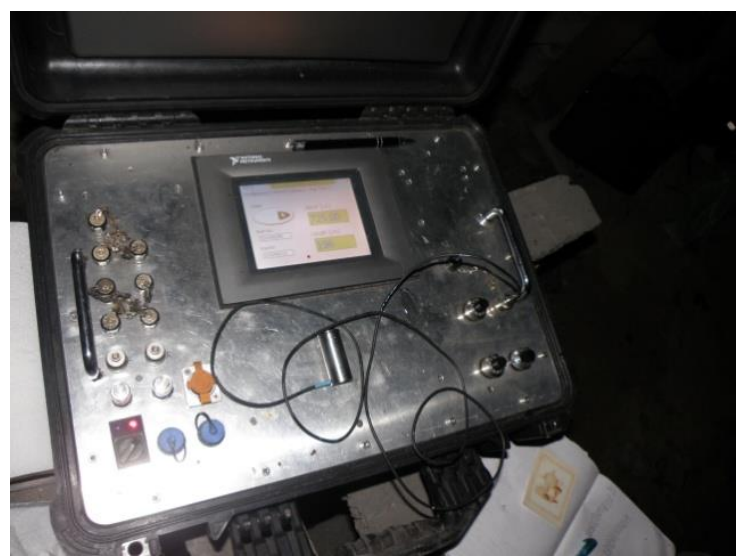

Fig. 14. The portable measuring system underground.

The standard deviation for in situ measurements is much greater than in laboratory conditions and that is explicable, as conditions are more severe.

For measured lengths the average value, standard deviation and combined standard measurement uncertainty were calculated. Type B evaluation of measurement uncertainty was evaluated according to similar assumptions as in the laboratory stage. The influence of rock strata in which rock bolts are installed seems to be not so crucial. The results obtained both in laboratory conditions, where rock bolts were installed in cement tubes, and in the experimental coal mine (sand stone rock strata), do not differ decisively.

Though from practical point of view the easiest way to attach the ultrasonic transducer (probe) to the investigated object is using hands, when a rock bolt is protruding from a roof strata hand held attachment may not be the optimal solution. A mechanical attachment is worth consideration.

On the whole, the results were quite satisfactory. The results of realized work increased knowledge of the problems encountered in the process of measurement of rock bolt length and gave important practical experience. The method seems to be relevant for this type of measurements.

\section{CONCLUSIONS}

The developed method enables the identification of the length of rock bolts installed in road ways. It may also be used in other areas where diagnostics purposes are demanded, support systems in building or tunneling for example. It uses ultrasonic transducers (probes) and National Instruments analog and digital modules.

The results seem to be quite satisfactory and showed that it is possible to assess the quality of rock bolts in a complex way.

Additional work is necessary to improve the contact between surfaces of a transducer and a diagnosed object, but new types of ultrasonic gauges may solve the problem. Though sensitivity of the method is quite promising and acceptable, the sensitivity of the method is $0.005 \mathrm{~V}$, the influence of noise in the reflected signal should be eliminated with the use of additional filters. The use of oscilloscope probes is seen as helpful or even necessary.

\section{SOURCE OF FUNDING}

The realised research was financed by Polish Ministry of Science and High Education, project no 11060317.

\section{REFERENCES}

1. Anatolik $Ł$. The ways of ultrasonic tests development using example of the railway axles examination. Problemy Kolejnictwa. 2014; 163.

2. Bačić M, Gavin K, Kovačević S. Trends in nondestructive testing of rock bolts. Journal of the Croatian Association of Civil Engineers GRAĐEVINAR. 2019;71(10):823-831, https://doi.org/10.14256/JCE.2727.20.

3. Beard MD, Lowe MJS. Non-destructive testing of rock bolts using ultrasonic waves. International Journal of Rock Mechanics and Mining Sciences. 2003; 40: 527-536.

4. Bergman S, Krauland N, Martna J, Paganus T. NonDestructive Field Test of Cement-Grouted Bolts With the Boltometer, 5th ISRM Congress, Melbourne, Australia. 1983.

5. Bishop RH. Learning with LabVIEW, Prentice Hall, New Jersey, 2001.

6. Denghong $\mathrm{X}$, Tian $\mathrm{H}$, Xiandong $\mathrm{L}$, Yingchun $\mathrm{S}$. Localization approach of damage in welded joint based on acoustic emission beamforming. Proceedings of the ASME 2014 International 
Mechanical Engineering Congress and Exposition, IMECE2014-37658. Montreal, 2014.

7. Gangbing S, Weijie Li, Bo Wang, Siu Chun MH. A Review of rock bolt monitoring using smart sensors. Sensors. 2017;17:776; https://doi.org/10.3390/s17040776.

8. Ghaffari B, Lazarz K, Ondrus D, Maev R, Titov S, Bogachenkov A, A matrix array technique for evaluation of adhesively bonded joints. SAE 2012 World Congress \& Exhibition. 2012-01-0475 https://doi.org/10.4271/2012-01-0475.

9. Haneol K, Hafeezur R, Wahid A, Abdul Muntaqim N, Jung-Joo K, Jonguk K, Hankyu Y. Classification of factors affecting the performance of fully grouted rock bolts with empirical classification systems. Applied Sciences. 2019;9:4781. https://doi.org/10.3390/app9224781

10. Hyett A, Mitri H, Spearing A. Validation of two new technologies for monitoring the in situ performance of rock bolts. Proceedings of the $7^{\text {th }}$ International Symposium on Rockbolting and Rock Mechanics in Mining. AIMS 2012: 177-190.

11. Kaczmarek R. The analysis of accuracy of determination of a point-type discontinuity position in ultrasonic testing using a double-transducer probe. Welding Technology Review. 2015;87(10).

12. Kidybiński A, Nierobisz A, Masny W. Maintenance of an opening affected by tremor enforced within nether roof strata. Proceedings of the Rockbursts 2005 Conference: 41-52. Central Mining Institute, Poland.

13. Li Charlie C. Principles of rock bolting in high stress rock masses. Mining \& Environment. 2010; 2(1): 133-143.

14. Li Charlie C. Principles of rock bolting design. Journal of Rock Mechanics and Geotechnical Engineering. 2017;9(3):396-414. https://doi.org/10.1016/j.jrmge.2017.04.002.

15. Mackiewicz S. Basic parameters of ultrasonic probes and their impact on quality of ultrasonic examination. Welding Technology Review. 2016; 88(10).

16. Randall RB. Mechanical vibration and shock measurements. Bruel \& Kjaer handbook. Naerum, 1982:122-129.

17. Ming L, Weijie L, Mingzhang L, Gangbing S. An automatic extraction algorithm for measurement of installed rock bolt length based on stress wave reflection. Measurement. 2018; 122: 563-57. https://doi.org/10.1016/j.measurement.2017.07.032

18. Mingzhang L, Weijie L, Bo Wang, Qingqing F, Gangbing S. Measurement of the Length of Installed Rock Bolt Based on Stress Wave Reflection by Using a Giant Magnetostrictive (GMS) Actuator and a PZT Sensor. Sensors. 2017;17(3):444. https://doi.org/10.3390/s17030444

19. Mitri HS. Design and development of a new rockbolt load measuring device. Etudes et Recherches, Raport $\mathrm{R}-308,202$.

20. Onoszko K. Methods Used in NDT, Informatyka, Automatyka, Pomiary w Gospodarce i. Ochrona Środowiska. 2012;4a:11-14.

21. Papadakis EP. Ultrasonic Instruments for Nondestructive Testing. Encyclopedia of Acoustics. John Wiley \& Sons, New York. 1997;1:683-692.

22. Remington PJ. Experimental and theoretical studies of vibrating systems. Encyclopedia of Acoustics. John Wiley \& Sons, New York. 1997: 715-734.
23. Ungar EE. Vibration isolation and damping. Encyclopedia of Acoustics. John Wiley \& Sons, New York. 1997: 843-855.

24. Signer SP, Rains RL. Effects of bolt spacing, bolt length, and roof span on bolt loading in a Trona mine. Proceedings of the 20th International Conference on Ground Control in Mining. Morgantown. West Virginia. 2001: 302-308.

25. Skrzypkowski K. Evaluation of rock bolt support for Polish hard rock mines. E3S Web of Conferences. 2018:01006. https://doi.org/10.1051/e3sconf/20183501006

26. Starkey A, Ivanovic A, Neilson RD, Rodger AA. The integrity testing of ground anchorages using Granit. 20-th International Conference on Ground Control in Mining, USA. 2001.

27. Ulusay R, Hudson JA. The complete ISRM suggested methods for rock characterization. Testing and Monitoring. Ankara, Turkey. 2007:1974-2006.

28. Villaescusaa E, Vardenb R, Hassella R. Quantifying the performance of resin anchored rock bolts in the Australian underground hard rock mining industry. International Journal of Rock Mechanics \& Mining Sciences. 2008; 45: 94-102.

\section{Received 2020.10.12}

Accepted 2021-04-16

Available online 2021-04-22

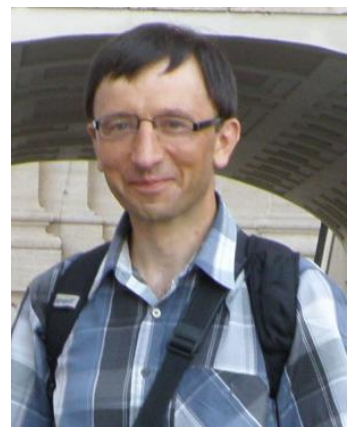

Andrzej STANIEK

graduated from Silesian Technical University in 1986. Ph.D. at Central Mining Institute in 2004. Fields of research: modal analysis of mechanical structures, NDT of rock bolt support system, buildings damage detection, metrology, environmental testing.

Hobby: climbing, skiing, swimming. 